ANZCA News Marsha Durham

SPECIAL THEME SECTION: CHILDREN'S TELEVISION POLICY: INTERNATIONAL PERSPECTIVES

Introduction Wendy Keys and David Buckingham

Children's television: A barometer of the Australian media policy climate Wendy Keys

Regulation of children's television in Australia: Past and present Nadia Mencinsky and Belinda Mullen

Production of Australian children's drama: Is there a future?

Kate Aisbett

Children's television policy in the United States:

An ongoing legacy of change Dale Kunkel

Public service goes to market: British children's television in transition

David Buckingham, Hannah Davies, Ken Jones and Peter Kelley

Children's television: The German situation

Ben Bachmair and Dirk Ulf Stötzel

Kumara kai or the Big Mac Pak? Television for six- to 12-year-olds in New Zealand Ruth Zanker

Pulling together the $\mathrm{ABC}$ : The role of $\mathrm{ABC}$ Online Fiona Martin

Misreading the crisis: Issues in Australian media representations of Indonesian politics Nick Fredman

It's never a five-day shoot: Queensland screen funding policy and the local animation industry Rebecca Farley

The film script as blueprint: Collaboration and moral rights Steven Maras

Reviews edited by Ben Goldsmith

Media Briefs: Press comment on the media, cultural and arts industries 


\section{$\mathrm{CMP}$ \\ (50)}

Issue

-February 2000 (no. 94)

May 2000 (no. 95)

August 2000 (no. 96)

November 2000 (no. 97)
Theme

Revisiting McLuhan

International Issues in Media Regulation

Telecommunications: Competition and Consumers
Theme editors

Hart Cohen

Tom O'Regan

Stuart Cunningham

Jock Given,

Gerard Goggin \&

Stephen McElhinney

Helen Wilson
Email address

h.cohen@uws.edu.au

t.oregan@mailbox.gu.edu.au s.cunningham@qut.edu.au

jgiven@comslaw.org.au

The Olympics Issue

\section{ADVERTISING RATES}

COSTS

$\begin{array}{lll}\text { Full page } & \$ 1250 & \text { (208mm vertical, 134mm horizontal) } \\ \text { Half page } & \$ 750 & \text { (100mm vertical, 134mm horizontal) } \\ \text { Inserts } & \$ 250 & \text { (pre-folded if larger than A5) }\end{array}$

Requests for reciprocal advertising are also welcomed from publications in related areas.

SPECIFICATIONS

Advertisements should be provided camera-ready as a good quality laser copy or bromide in black and white. Layout of advertisements can be arranged for a small surcharge.

CIRCULATION

Approximately 1000 copies nationally and internationally.

\section{BOOKING DEADLINES}

Advertising space should be booked by the 1st of the month prior to the publication month.

Advertising copy or materials should reach the Key Centre by the 9 th of the month prior to the publication month.

CONTACT

Publications Manager, Australian Key Centre for Cultural and Media Policy Facuity of Arts

Griffith University, Nathan Qld 4111

Phone: $\quad$ (+61) $738755350 \quad$ Fax: $(+61) 738755511$

Email: $\quad$ cmp@mailbox.gu.edu.au

Website: http://www.gu.edu.au/centre/cmp/MIACP.html 


\title{
CHILDREN'S TELEVISION: THE GERMAN SITUATION
}

\begin{abstract}
This article provides an overoiew of the current state of ana future prospects for cinildren's television in the Federal Republic of Germany. It begins with a brief description of current television provision for children, and of children's viewing patterns, and it suggests that views of children's relations with the medium are heavily influenced by social class. The article goes on to describe the structural features of broadcasting and of media regulation in Germany, paying particular attention to the federal structure and the balance between public and private. The implications of this situation for children's programming are then analysed, with particular attention paid to the heavy regulation of advertising on free-to-air channels, and the need to protect children's slots in the context of a general move towards specialist channels. The article concludes by outlining the terms of recent public debates about the social purpose and quality of children's television.
\end{abstract}

There are nearly nine million children in Germany today, representing about 13 per cent of the population. ${ }^{1}$ The proportion of children is decreasing, however: three- to five-year-olds constitute a mere 3 per cent, while six- to nine-year-olds and nine- to 13-year-olds constitute 5 per cent each. The Federal Bureau of Statistics estimates that the proportion of three- to five-year-olds will drop below 2 per cent by the year 2007. Only nine television stations had significant or high percentages of child viewers in 1997 and 1998.

Table 1: Market share of broadcasters, 1 January to 31 March $1999(\%)^{2}$

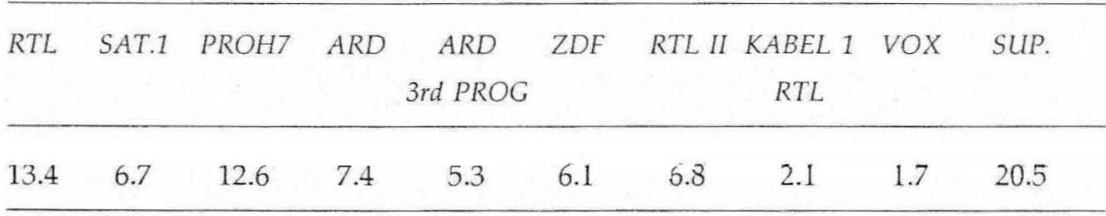

Whereas Kinderkanal ('The Children's Channel', a specialist children's channel), ZDF and ARD (including one national and eight regional programs, the 'Third Program') are public channels, SuperRTL, RTL2, RTL, SAT1 and Pro7 are private.

The provision of dedicated children's programs is declining. In 1998, private stations experienced a reduction from nearly 50 hours on weekdays to about 20 hours. Since the introduction of Kinderkanal, the nationally broadcast public channels ZDF and ARD have concentrated their provision of children's programs at weekends. 


\section{THE PATTERN OF CHILDREN'S TELEVISION VIEWING IN GERMANY}

In Germany, no other age group watches less TV than children. On average, children watch little more than 1.5 hours a day, whereas adults spend twice that time in front of the screen. Average viewers (that is, those who watch between 30 and 119 minutes a day) switch on the TV on 18 days each month: 12 days therefore remain free of television (Simon, 1998). From the perspective of these figures, enough 'TV-free' time remains for activities that are often seen as appropriate for children, such as learning and playing with friends.

Of course, there are 'heavy viewers' among German children. One quarter of all children $^{3}$ have a daily viewing time averaging more than two hours, while 12 per cent average three hours. Almost one-fifth of the youngest age group are heavy viewers, averaging more than two hours of TV per day. Roughly half of these heavy viewers are between 10 and 13 years old, and the majority are boys.

Early evenings, between 6.00 and 9.00 p.m., and weekend mornings are children's 'prime time'. Among the youngest viewers (three- to five-year-olds), the ratings peak at 6.00 p.m. on weekdays (at around 18 per cent of viewers), although their main viewing time is Sunday morning, with a distinct peak at noon. Saturday and Sunday mornings are also prime time for younger school children (six- to nineyear-olds), although they too watch a good deal in the evenings. About one-third of older children are tuned in on Fridays and Saturdays between 9.00 and 10.00 p.m., although during the week and on Sundays they are required to go to bed earlier because of school.

Older children watch programs for teenagers and adults. ${ }^{4}$ TV stations also serve different age groups differently. In 1998, the youngest age group (three to five years) preferred SuperRTL (21.2 per cent), followed by Kinderkanal (14.1 per cent) - in other words, dedicated children's programs. Older children (10-13 years) were more likely to tune in to RTL (17.6 per cent) and Pro7 (15.8 per cent) that is, to stations with less typical or dedicated children's programming. ${ }^{5}$

In terms of gender, preferences become more stereotyped with increasing age. Thus girls tend to avoid 'dangerous' entertainment, preferring fantasy characters, and tune in to series and daily soaps about love, friendship and social relationships. Older boys prefer sports programs, as well as science fiction or thrillers, whereas these are less popular with 10-13-year-olds. Girls also tend to watch slightly less than boys do, and fewer 'heavy viewers' are girls.

\section{VIEWS OF CHILDREN'S RELATIONS WITH TELEVISION}

Dominant public opinion in Germany would prefer a childhood without, or with little, consumption and with strict regulation of children's access to the entertainment medium of TV. Bettina Hurrelmann et al. (1996: 72ff.) have investigated parental perceptions of the 'problems' of TV in a wide-ranging empirical enquiry. How do parents regulate their children's access to the TV set? 
Two aspects are decisive here. On the one hand, parents do not want their children to watch TV too late in the evening. On weekdays, children are not supposed to be watching after 7.00 or 8.00 p.m., and on no account after 9.00 p.m. On Sunday evenings, parents prefer to have their children involved in family life without TV much earlier in the evening. The second aspect of parental regulation is to do with program content. In terms of program content, mothers tend to entrust their children to public channels rather than private stations. Fathers tend not to share these preferences, however.

The decision about which stations are more suitable for children also depends to a large degree on social class. Working-class parents do not object to their children tuning into private stations, whereas middle- and upper-class parents prefer public channels for their children (Hurrelmann et al., 1996: 59). In the middle and upper classes, however, the traditional concept of childhood (which provides the basis for the preferred genres and formats of public channels) leads to a discrepancy between 'practices and pedagogical attitudes' (Hurrelmann et al., 1996: 62): despite what their parents may wish, these children have developed a closer affiliation to the genres and formats of private channels.

If such parents do get involved with television at all, they see it as an educational tool for children - as a way of expanding knowledge that is useful for school, encouraging critical thinking and stimulating the children's imagination (Hurrelmann et al., 1996: 77). Parents with children at elementary school age almost never identified television as 'very good' for their children, and the grade 'good' was only given by 6 per cent of the mothers and 4 per cent of the fathers. Evaluations like 'satisfactory' (27 per cent mothers, 31 per cent fathers) and 'sufficient' (34 per cent mothers, 29 per cent fathers) prevailed. This evaluation seems to be supported by parents' assumption that television often or very often confronts children with violence (29 per cent mothers, 26 per cent fathers). Only one-fifth of these parents think that TV violence does not represent a relevant problem (Hurrelmann et al., 1996: 83). According to Hurrelmann et al., (1996: 83), the confrontation of children with sexuality on TV is a lesser problem for parents. Parents tend to see negative consequences for boys if they prefer action films and private channels, particularly if they are at the same time frequent viewers, if they are allowed to watch TV late in the evening, and if parents apply their educational rules inconsistently.

According to the research of Six et al. (1998: 439), the majority of educators in nursery schools view modern technological media on the whole as a powerful and influential opponent of their educational endeavours, and condemn their harmful influences on their children. Educators consider themselves competent TV consumers, who watch less and are led by acceptable motives, although they think that parents act as bad examples to their children.

However, this judgment is not based on knowledge about how much and what children watch, or the motivations that lead them to do so. Thus educators usually 
overestimate the viewing amount of nursery school children (age three to six years) by a considerable degree, and elementary school teachers tend to make the same kind of miscalculation (Frey and Six, 1997). Their own experiences as mothers with their own children do not seem to enter into these estimates. The educators' attitudes in terms of the children's favourite programs are likewise determined by lack of experience (Six et al., 1998: 259ff.): they are not familiar with programs which they consider problematic (e.g. He-Man, Teenage Mutant Ninja Turtles, Power Rangers) from their own experience, but only from secondary sources, such as conversations with parents, colleagues and friends, newspaper articles and books. This evaluation complex clearly exhibits features of a prejudice, because it excludes contradictory facts, and because the person making the judgment remains on the positive side.

\section{STRUCTURAL FEATURES OF TELEVISION BROADCASTING IN GERMANY}

In the Federal Republic of Germany, private stations (which are exclusively financed by advertising and sponsors) coexist with public channels (which are financed by taxation as well as advertising). This coexistence of stations with different financing sources is referred to as the Dual Broadcasting System.

Media law is likewise differentiated into a private and a public sector, both of which are regulated by the Broadcasting Contract of the Federal States (Länder). This contract is laid down by the States by means of hearings. The Federal Constitutional Court's very first judgment on broadcasting in 1961 clearly indicated how responsibilities for broadcasting should be apportioned in Germany, in line with its federal structure. It ruled that broadcasting legislation in the narrow sense fell within the jurisdiction of the Federal States. This covers fundamental decisions on the organisational structure and financing of the public broadcasting corporations, the licensing of private television stations, as well as basic directives on the content of programs to be broadcast within the framework of the constitutional mandate. On the other hand, the federal government is responsible for all matters pertaining to telecommunications law, which also covers the technical transmission of TV programs, and for copyright.

Media law is subject to the jurisdiction of the Federal States, since they are responsible for cultural matters in Germany, and the media are viewed as cultural rather than economic goods. Thus the Federal Broadcasting Contract forms a binding legal framework which is negotiated by the representatives of the Federal States, namely the Ministers President. Since the Federal States often pursue differing interests, negotiations about media law can prove quite lengthy and complicated.

The public broadcasting corporations are established under public law - in other words, they are organisations established by virtue of state law or an inter-state agreement determining their function and structure. All public broadcasting institutions are headed by a Director General, who has sole responsibility for that 
station's programs. The Director General is subject to control by two bodies: a management committee, usually referred to as the Board of Administration, which oversees the administration and finance; and a program monitoring committee, usually known as the Broadcasting Board. Since the function of the latter is to ensure plurality of opinion, it is composed of representatives of all 'socially relevant groups', such as political parties, trade unions, churches, associations and so on. In addition, each TV station is monitored by a Federal State and its representatives. Whereas this structure remains difficult to comprehend from the outside, it was introduced in postwar Germany by the Allies in order to prevent one or a few groups abusing the media as an instrument of political power. The experiences with the National Socialist regime were a leading reason for this.

Children's TV - whether public or private - is the focus of many of the tensions inherent in the Dual Broadcasting System. This results not only from the differing legal framework, but also from the means of financing. A public children's channel like Kinderkanal is primarily financed by licence fees and currently has about 100 million DM per year at its disposal. Licence fees are paid by everyone who possesses a serviceable television set - that is the sole criterion, irrespective of whether the set is actually used. Private 'Free-TV' stations like SuperRTL, however, are exclusively financed by advertising and sponsors. Digitally broadcast channels like the Disney Channel attempt to finance their programs exclusively by means of subscription fees ('Pay-TV').

The basis of success for a TV station is its distribution by satellite or cable. Again, there are differences here between public and private channels. A public channel must be available by cable (since it is financed by licence fees) and may be distributed via satellite if it is prepared to pay the rental charges for satellite transmission. Private stations may use cable provided there is enough capacity available, and may also be broadcast by satellite provided they are able to finance this.

Full technical coverage (cable and satellite) in Germany is estimated to cost about 16 million DM per year. Altogether, there are about 19 million cable households in Germany, 4 million of which are terrestrially supplied, and about 11 million of which receive their programs via satellite. Consequently, cable is the primary mode of distribution. Since cable capacity is limited to about 33 channels, competition is accordingly high.

Apart from the financial structures for cable broadcasting, the media administrative body of the Federal State (Landesmedienanstalt) controls the right to feed programs into the cable network. Policies on cable access reflect the imperatives of local politics. In recent years, the Federal States have developed a competitive approach to the allocation of private channels. It is understood that a channel which has been licensed in a particular Federal State will be granted the right to broadcast on the respective local cable network. Consequently, media distribution is a highprofile political issue, not least in respect of the relations between Federal States. 
The different modes of financing (taxation versus advertising), the highly differentiated broadcasting policies, the so-called cable bottleneck (i.e. the technical limit of 33 channels), a strong public must-carry program offer of almost 18 nationally broadcast channels, and an offer of more than 20 private channels, demonstrate that Germany is a highly fragmented and segmented market for TV products. Nowhere else in Europe can a comparable density of advertising and more confusing media laws be found. Nonetheless, the advertising market on TV, with its budget of more than 11 billion DM in 1998, makes the market attractive for many companies.

\section{REGULATION OF CHILDREN'S TELEVISION}

Since the introduction of television in the 1950s, the provision of children's TV in Germany has found itself caught in some of the fundamental tensions that characterise social policy and media law. This can be demonstrated by the way in which children were kept out of cinemas - an attitude which has partly, and with little controversy; been transferred to TV regulation, reinforced by discussions about how TV damages eyesight and body posture. Also, children's TV has to be regarded as a mirror of socially relevant trends and developments. Until the mid1980s, the relatively sparse provision of children's TV was under public control. It was free of advertising, and public and academic discussion revolved more around the content and pedagogical approach of children's television. The introduction of private channels in the mid-1980s in Germany had a strong impact on this. Private stations offered a rich spectrum of children's programs, albeit financed by advertising. In this context, there were numerous attempts to remove advertising from children's programs altogether, and several studies of the effects of advertising on children were undertaken (Charlton et al., 1995). Since private stations rely entirely on advertising for their revenue, a complete ban on advertising during children's programs was politically impracticable. This led to numerous restrictions and conditions being imposed by the Federal Broadcasting Contract, and to advertising guidelines being drawn up by the responsible Boards of Regulation (Landesmedienanstalten), as well as voluntary commitments on the part of private stations.

As a result, there is an extensive amount of legal protection for children and teenagers in Germany, in the form of an age-based regulatory system for both programs and advertising - particularly for children's television. Altogether, there are three elements that seek to ensure active protection of minors in terms of advertising. To begin with, there are the Common Guidelines of the Media Boards of Regulation for Advertising, intended to achieve a separation of advertising and program content, and for sponsorship of TV and radio broadcasts (the Advertising Guidelines). They are an interpretation of section 6, paragraph 1, sentence 2 of the Federal Broadcasting Contract, which states that 'Advertising also addressed to or employing children or adolescents may not prejudice their interests or exploit their inexperience'. 
Furthermore, the Advertising Guidelines place specific restrictions on advertisements addressing children. These are particularly against the law if they:

- encourage children to make their parents buy a product;

- show children engaging in dangerous or illegal actions;

- confront children with misleading advertisements or exploit children's passion for games (like competitive puzzles or games of chance);

- contain direct requests to buy something;

- exploit children's gullibility or inexperience;

- advertise products which are key components of the surrounding children's programs.

Spot advertisements are likewise prohibited from interrupting children's programs, in an attempt to reduce the flood of advertising messages towards children. Also, most private stations pursue additional internal policies which prevent (for example) the advertising of alcoholic drinks in the vicinity of children's programs or on specialist satellite channels. In Germany, commercials during children's programs also have to be distinctly separated from the main transmission by means of a brief trailer, designed to enable even young children to realise the difference between advertisements and programs.

There is also a board of self-regulation that oversees content issues in advertising, the German Advertising Council (Deutscher Werberat). Without regard to the medium employed, this committee judges advertising by the following criteria:

- the Civil Law;

- legal regulation of advertising (competition law, etc.);

- a distinctive moral code of manners, decency and ethics, reflecting the norms and values of society.

One consequence of this regulation of advertising is that children's programs on private channels are currently experiencing difficulties with exclusively advertisingbased financing. There are three reasons for this:

1 The media market for exclusive children's products (like toys) is not only limited, it is also very much subject to seasonal variations in consumption habits. The advertising industry usually advertises before Christmas, since this is the sales focus for children's products.

2 On the other hand, German marketing strategists mostly concentrate on the well-to-do core target group of 14-49-year-olds; by doing this, they fail to see that children are tomorrow's consumers - that they purchase, decide purchases and influence purchases. 
3 The third and most crucial point is that the existing proliferation of advertising regulations renders the surroundings of children's programs unattractive for the advertising industries and hence for TV stations.

It is also a financial problem for the advertising industries if one commercial has to be produced in two different versions in order to remain 'rule-compliant' (that is, suitable for adult programs and children's programs) because of the numerous regulations. Since merchandise relating to children's programs must not be advertised in the vicinity of those programs, a necessary additional source of finance for children's programs is effectively removed.

The thicket of regulations for children's advertising is so dense that agencies and media planners shrink from investing in children's advertising. An example of this 'regulation frenzy' is section 3, paragraph 4 of the Advertising Guidelines, according to which advertising during children's programs is illegal if it contains 'influential elements which are also part of the children's program before or after the commercial'. Any producer not directly concerned with media and advertising law is bound to enter a state of 'creative emergency' here. It is for this reason that there have been increasing calls to liberalise advertising regulations. Meanwhile, in order to evade these legal obstacles, the largest private children's channel (SuperRTL) is licensed as a family channel rather than a children's channel.

The success of private stations with children's programs in the mid-1990s was obvious. The public broadcasters in Germany saw a significant reduction in their share of the market under the influence of market segmentation and fragmentation. Only a political decision was capable of stopping this trend. Thus the private stations achieved a liberalisation of media ownership laws in 1995 and, in return, ARD and ZDF as public providers obtained the chance to establish two more thematic channels. These were the documentary channel Phoenix and the children's channel Kinderkanal, both financed through taxation. Since public channels have priority by virtue of belonging to the so-called 'must-carry' section of cable, Kinderkanal drove the private children's channel Nickelodeon (which had been launched in 1995) from its 'native' cable slots, eventually pushing it out of the German market.

The legal and technological path to digital television has now been laid out. Alongside already existing Pay TV children's channels, the Disney Channel was scheduled to start broadcasting in autumn 1999 on DF1's digital platform probably free of advertising. In this way, program content which interests children is being shifted into the Pay TV niche. More arguments for further advertising restrictions on 'free-to-air' children's TV in Germany can be expected. 


\section{IMPLICATIONS FOR BROADCASTING POLICY}

\section{PRIVATE CHANNELS}

Private children's channels are exclusively financed by advertising earnings. Children's programs - including those of commercial TV stations - are just as much part of the range of TV as news and sports. In order to maintain and expand this multitude of offerings for children, a protected space is required for children's programs in the private sector - as one of the requirements of media policy. Children's program slots have to be protected to just the same degree as they are supposed to be shielded from the allegedly harmful influence of advertising. This means that alternative conceptions of financing have to be drawn up and defined. Since children's programs enrich the offerings of cable networks, they should be required to fund children's programs with a basic payment taken from the cable fees of network providers, thus making them more independent from advertising. A yearly contribution of 10 Pfennigs per cable household is estimated to be sufficient to secure private children's channels and to maintain program variety on a longterm basis. If more than 35 per cent of the weekday programming of private providers is deemed suitable for children, it is also conceivable that they might be supported by the state.

Due to the difficult situation in the advertising market, alternative forms of financing also have to be encouraged. Merchandising is one possible form, but this requires that these products may also be promoted in the vicinity of children's programs.

Constantly changing cable channel allocations require high marketing investments to enable children to find 'their' channels - a problem that applies to both private and public stations. Differing allocations - often changing not only from one Federal State to the next, but also from city to city, in some cases even on a yearly basis - pose enormous difficulties for private stations.

Finally, German production of children's television is also impeded by work protection regulations for children. The production of children's programs is rather problematic, since children are not allowed (by industrial safety laws and laws for the protection of minors) to be available for filming for more than one and a half hours a day.

\section{PUBLIC CHANNELS}

Altogether, public channels have more than 11 billion DM of licence fee payments at their disposal. The public Kinderkanal is free of advertising and exclusively financed by fees, and it therefore represents the main alternative to the multitude of private children's programs. Public children's programs used to be distributed among several stations until 1997. With the introduction of Kinderkanal, children obtained a fixed, recognisable 'home' in the flood of channels. The founding of this independent children's channel in 1996, and its launch on 1 January 1997, was also consequential in terms of competition with other private channels, which used to broadcast series and talk shows in the afternoons that were seen as unsuitable for children. 
Kinderkanal is the result of program bundling of the main programs of the public channels ARD and ZDF. Previously, children's programs also featured during prime time on ARD and ZDF, although there was pressure to include more massaudience programs, which would be attractive to advertisers. ARD and ZDF were of the opinion that a dedicated children's channel would be the best way of satisfying the needs and preferences of their young target group. The argument for offering child-oriented and non-violent programs to children at any time, but especially during their preferred watching times, thus lent a pedagogical as well as an economic rationale to the basic concept of Kinderkanal. The new channel also encouraged a focusing of specialist resources: a new station dedicated to children allowed for greater experimentation with new formats, such as live broadcasts and the like. Also, longer broadcasting formats like fairytale films are not supported by private stations, since they cannot be interrupted by advertisements and hence are difficult to finance. However, the decision to introduce Kinderkanal was also of political importance, because in return for a children's channel and a non-fiction channel for the public stations, private stations obtained a liberalisation of the laws on media ownership.

As compared with private children's program providers, Kinderkanal has at its disposal almost 40 years of programming experience as well as productions from the libraries of public channels, which cannot be produced in the same way or purchased by private stations. After being on air for almost three years, it has achieved a strong market share of more than 15 per cent of its target group of three- to 13-year-olds. Many attempts on the part of private stations to push this annoying competitor off the market have failed. In order to compete with other stations and formats, however, Kinderkanal requires greater financial resources. The current yearly budget of 100 million DM will not be enough to keep pace with the digital services of Disney and others: idealistic conceptions of children's programming will inevitably collide with the merchandising machineries of private companies, for whom the broadcasting of a program is but the starting point of their marketing strategies.

\section{THE PROMOTION OF CHILDREN'S TELEVISION}

Apart from these economic factors, public discussion rages around the quality of children's programs. Is public children's television more valuable in terms of quality because it is financed by licence fees? Is private children's TV of inferior quality because the stations are commercially oriented? Academics, representatives of interest groups, political parties and finally also churches (as the largest representative of interest groups in Germany) are all participating in this debate. These groups met at a round table which began in 1995, chaired by the two major churches. This round table - entitled 'Quality Television for Children' - is considering the structural prerequisites that are needed to support children's television. In its initial phase, it defined general quality standards, and it is currently attempting to draw the attention of politicians and of the media to the structural problems of children's television. So far, the most notable success of this committee lies in its ability to overcome divergent economic and institutional interests in 
favour of considering children's interests. It has drawn up the following guidelines, which are to be considered primarily programmatic and declamatory:

Television plays a major role in the everyday life of children, in their development, their orientation, and their efforts to cope with their lives. Childhood today is 'media-tised' childhood, lived in a confusing world. Therefore, program planners share a special responsibility in terms of TV with other social groups, parents, educators and politicians. In the light of current program developments and new technological possibilities for broadcasting and consuming, children's television in Germany requires a wide-ranging promotional initiative. The stations, producers, groups, associations and churches participating in the Round Table therefore demand the promotion of children's television by means of maintaining agreed standards, ensuring continuous public discussion and encouraging variety and quality.

They agree on the following theses concerning children's television:

1 Children are entitled to high-quality TV programs matching the professional and aesthetic standards of other programs.

2 Children's programs should offer a multitude of genres, formats and contents. They should present these in dramaturgic forms suitable for children and allow innovation and originality.

3 Children's programs should entertain and inform. They should take up children's needs and expectations, their hopes and curiosities. They should take into consideration children's experiences and offer them help in orienting themselves to the world. They should provide room for individual emotions, and encourage, empower and aid them in developing in ways appropriate to their age.

4 Children's programs should take children's questions, issues and interests seriously. They should take into account age- and genderspecific differences, promote children's awareness of their own living environment as well as of foreign cultures, and support their respect for the latter.

5 Children's programs require stable broadcasting times. They must be scheduled according to age and be easily locatable for children.

6 Children's programs require a sound financial background as well as qualified program contributors. This assumes different forms of budgeting.

The extent to which these principles can be implemented clearly depends upon a more general political will. If they are not, there is a risk that children's television may be ground down in the tension between society's demands and commercial principles. 
1 The legal 'end' of childhood in Germany is at the end of the 13th year. Usage data on children are empirically gathered by the ADF/GFK for the age groups of three- to five-year-oids, six- to nineyear-olds, and 10- to 13-year-olds. There are no usage data for younger children. A survey of children's television in Germany can be found in: Zentralstelle Medien der Deutschen Bischofskonferenz/Gemeinschaftswerk der Evangelischen Publizistik (1998); and Erlinger et al. (1995).

2 Due to copyright restrictions, there are no market figures for Kinderkanal. During its broadcasting time (until 7.00 p.m.), Kinderkanal has a market share of roughly 17 per cent, which puts it in second position after the market leader, SuperRTL.

3 This separation into 25 per cent for each extreme group (heavy viewers, 'low-profile viewers) and 50 per cent of average viewers is suggested by Simon (1998).

4 AGF-GFK/Medienforschung SRTL.

5 The figures given are for the two highest-ranking stations. The figures for Kinderkanal have risen considerably in 1999 , but precise numbers are difficult to obtain due to the fact that the channel is shared with ARTE, the Arts channel.

\section{REFERENCES}

Charlton, Michael, Neumann-Braun, Klaus, Aufenanger, Stefan, Hoffmann-Riem, Wolfgang et al. 1995, Fernsehwerbung und Kinder: Das Werbeangebot in der Bundesrepublik Deutschland und seine Verarbeitung durch Kinder. Volume 1: Das Werbeangebot fur Kinder im Fernsehen. Volume 2: Rezeptionsanalyse und Rechtliche Rahmenbedingungen, Leske \& Budrich, Schriftenreihe Medienforschung der Landesanstalt fur Rundfunk Nordrhein-Westfalen, Opladen.

Erlinger, Hans Dieter et al. (eds) 1995, Handbuch des Kinderfernsehens, Ulschlager, Konstanz.

Frey, Christoph and Six, Ulrike 1997, 'Kriterien zur Bewertung des "Kinder-Fernsehens"', in H.-D. Erlinger (ed.), Kinder und der Medienmarkt der 90er Jahre, Westdeutscher Verlag, Opladen, pp. 177-96.

Hurrelmann, Bettina, Hammer, Michael and Stelberg, Klaus 1996, Fumilienmitglied Fernsehen Schriftenreihe Medienforschung der Landesanstalt fur Rundfunk Nordrhein-Westfalen, vol. 20, Leske \& Budrich, Opladen.

Simon, Erk 1998, 'Wie sehen Kinder fern? Nutzungsmuster der 3- bis 13-jahrigen Fernsehzuschauer', in Zentralstelle Medien der Deutschen Bischofskonferenz/Gemeinschaftswerk der Evangelischen Publizistik (eds), Debatte Kinderfernsehen. Analyse und Bewertung von TV-Programmen fur Kinder, Vistas, Berlin, pp. 63-76.

Six, Ulrike, Frey, Christoph and Gimmler, Roland 1998, Medienerziehung im Kindergarten: Theoretische Grundlagen und Empirische Befunde Schriftenreihe Medienforschung der Landesanstalt fur Rundfunk Nordrhein-Westfalen, vol. 28, Leske \& Budrich, Opladen.

Zentralstelle Medien der Deutschen Bischofskonferenz/Gemeinschaftswerk der Evangelischen Publizistik (eds) 1998, Debatte Kinderfernsehen. Analyse und Bewertung von TV-Programmen fur Kinder, Vistas, Berlin. 
Ben Bachmair is Professor of Pedagogy and Media Education at the University of Kassel, Germany. His main research interests are: Children, TV and Everyday Life; Media Education and Postmodernity; Symbolic Mediation and the Cultural Process.

Dirk UIf Stotzel was formerly Director of Research and Development for Nickelodeon and MTV in Germany. He is now Director of New Media at Deutche Telecom. He has published widely on the history, forms and functions of children's television in Germanu. 